\title{
ELECTROCHEMISTRY IN PYRIDINE-IV. CHEMICAL AND ELECTROCHEMICAL REDUCTION OF PYRIDINE*
}

\author{
A. Cisak $†$ and P. J. Elving \\ Department of Chemistry, The University of Michigan, \\ Ann Arbor, Michigan, U.S.A.
}

\begin{abstract}
The cathodic polarographic wave observed for solutions of $\mathrm{AlCl}_{3}$ in pyridine is due not to reduction of Al(III), but to reduction of the solvent, in which process Al(III) plays an essential role, apparently by polarizing the pyridine through the formation of a Lewis acid-base adduct with the pyridine nitrogen. Macroscale electrolysis of pyridine solutions of $\mathrm{AlCl}_{3}$ at a mercury cathode results in the reduction of pyridine and the formation, after hydrolysis and air oxidation, of a complex mixture or copolymer of unsaturated polyamines and polyamides probably containing such

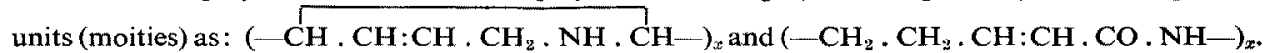
Essentially the same product is obtained by treatment of pyridine with $\mathrm{LiAlH}_{4}$. The reaction mechanisms proposed involve disruption of a $\mathrm{C}-\mathrm{N}$ bond in pyridine.
\end{abstract}

Résumé-La vague polarographique cathodique obtenue dans des solutions de $\mathrm{AlCl}_{3}$ dans la pyridine n'est pas due à la réduction de Al(III) mais à celle du solvant, dont le processus implique une participation essentielle de Al(III). Cette participation parait consister en une polarisation de la pyridine à la faveur de la formation d'un couple acide-base de Lewis grâce à l'azote de la pyridine. Macroscopiquement, l'électrolyse de solutions de $\mathrm{AlCl}_{3}$ dans la pyridine sur cathode-mercure, provient de la réduction de la pyridine et la formation, après hydrolyse et oxydation par l'air, d'un mèlange de complexes ou de copolymères de polyamines et polyamides non saturées, contenant probablement des motifs tels que: ( $\left.-\mathrm{CH} . \mathrm{CH}: \mathrm{CH} . \mathrm{CH}_{2}, \mathrm{NH} . \mathrm{CH}-\right)_{x}$ et $\left(-\mathrm{CH}_{2}, \mathrm{CH}_{2}, \mathrm{CH}: \mathrm{CH}, \mathrm{CO}, \mathrm{NH} \rightarrow\right)_{x}$. En traitant la pyridine par $\mathrm{LiAlH}_{4}$, on obtient des produits analogues. Le mécanisme proposé implique la rupture d'une liaison $\mathrm{C}-\mathrm{N}$ dans la pyridine.

Zusammenfassung-Die kathodische polarographische Stufe, welche an Lösungen von $\mathrm{AlCl}_{3}$ in Pyridin beobachtet wird, ist nicht der Reduktion von Al(III), sondern der Reduktion des Lösungsmittels zuzuschreiben, wobei $\mathrm{AlCl}_{3}$ eine ausschlaggebende Funktion ausübt, indem es offensichtlich durch Bildung eines Lewis-Säure-Base-Adduktes mit dem Stickstoff des Pyridins dieses zu polarisieren vermag. Elektrolytische Reduktion der Pyridin- $\mathrm{AlCl}_{3}$-Lösung in grösserem Masstab an einer Quecksilberkathode ergibt, nach Hydrolyse und Luftoxydation, ein komplexes Gemisch oder Kopolymer von ungesättigten Polyaminen und Polyamiden, wahrscheinlich Bausteine der Form

$$
\left(-\mathrm{CH}, \mathrm{CH}: \mathrm{CH} \cdot \mathrm{CH}_{2} \cdot \mathrm{NH} \cdot \mathrm{CH}-\right)_{x} \text { und }\left(-\mathrm{CH}_{2} \cdot \mathrm{CH}_{2} \cdot \mathrm{CH}: \mathrm{CH} \cdot \mathrm{CO} \cdot \mathrm{NH}-\right)_{x}
$$

enthaltend. Das analoge Produkt entsteht bei der Reduktion von Pyridin mit $\mathrm{LiAlH}_{4}$. Die vorgeschlagenen Reaktionsmechanismen beinhalten die Spaltung einer $\mathrm{C}-\mathrm{N}$-Bindung des Pyridins.

\section{INTRODUCTION}

IN THE course of a study ${ }^{1}$ of the polarography of inorganic salts in dry pyridine, ie in aprotic medium, the behaviour of Al(III) solutions was investigated. While these solutions gave good polarographic waves, elementary aluminium could not be obtained on macroscale electrolysis even after considerable current flow.

The reduction of pyridine in proton-rich media, eg reduction of the pyridinium ion in acidic solution, is well-known and leads to more or less hydrogenated pyridines, eg a mixture of piperidine and $\alpha, \alpha$ - and $\gamma, \gamma$-dipiperidyls ${ }^{2}$ or of piperidinc and tetrahydropyridine. ${ }^{3}$ The reduction of pyridium ion in pyridine has been described. ${ }^{4}$

The present paper discusses the evidence for (a) the electrochemical process involving reduction of the pyridine ring, (b) elucidation of the role of $\mathrm{Al}(\mathrm{III})$ in the

* Manuscript received 8 October 1964.

$\dagger$ Permanent address: Laboratory of Inorganic Chemistry, University of Warsaw, Warsaw, Poland. 
process, (c) nature and structure of the primary product produced and of its isolatable derivative after hydrolysis, and (d) the similarity of the products of the electrochemical and chemical hydride reductions of pyridine.

\section{ELECTROCHEMICAL REDUCTION OF PYRIDINE}

\section{Polarography of aluminum chloride in pyridine}

The pyridine complexes of $\mathrm{AlCl}_{3}$ have been studied by a variety of techniques..$^{5-8}$ Aluminum chloride apparently exists predominately as the dimer in "inert" solvents. However, in solvents whose molecules have electron-donor properties stronger than those of the chlorine atom, the bridged chlorine atoms are displaced by the stronger base, opening the dimer and producing the monomeric solvated aluminum chloride. (The latter may show salt-like properties in solvents of sufficiently high dielectric constant.) Anhydrous aluminum chloride vigorously reacts as a Lewis acid with pyridine, which is a Lewis base, forming an adduct with the evolution of considerable heat ${ }^{9}$

$$
0.5 \mathrm{Al}_{2} \mathrm{Cl}_{6}+3 \mathrm{C}_{5} \mathrm{H}_{5} \mathrm{~N} \rightarrow\left(\mathrm{C}_{5} \mathrm{H}_{5} \mathrm{~N}\right)_{3} \mathrm{AlCl}_{3}+47 \cdot 8 \mathrm{Kcal} \text {. }
$$

The resulting salt is fairly soluble at room temperature in pyridine, in which it forms well-conducting solutions. Some measurements indicate that the $1: 1 \mathrm{AlCl}_{3}$-pyridine complex is the most stable of the series $\mathrm{AlCl}_{3}(\mathrm{pyr})_{m}$.

Two polarographic waves are observed for pyridine solutions of $\mathrm{AlCl}_{3} .{ }^{1}$ The first small wave, whose height is independent of $\mathrm{AlCl}_{3}$ concentration, seems to be due to traces of moisture. The height of the second and principal reduction wave $\left(E_{1 / 2}=-1.00 \mathrm{~V}\right.$ vs mercury pool, $-1.45 \mathrm{~V}$ vs $\mathrm{NAgE}$; the latter reference electrode has been described ${ }^{1}$ ) is directly proportional to $\mathrm{AlCl}_{3}$ concentration. Since polarographic study gave no clear answer as to the nature of the faradaic process corresponding to the latter wave, macroscale reduction of the $\mathrm{AlCl}_{3}$-pyridine system was investigated.

Electrolytic experiments, described in the Experimental section, gave consecutively four products, A, B, C and D, the last two being stable under normal laboratory conditions. Only product $A$ results from an clcctrochemical reaction; the other products appear in subsequent reactions, which will be discussed jointly for the products of electrochemical and hydride reduction of pyridine. Essentially, A, the primary observed reduction product, is dark brown to black in colour; on alkaline hydrolysis and air oxidation, A yields an oily yellowish decomposition product $B$ and a pale yellow polymeric product $C$; the latter product on exposure to air and heat forms product $\mathrm{D}$.

The possibility was considered that part of the stable product (C and D) obtained during work-up of the primary product $\mathrm{A}$ might be a polypyridyl. (The largest polypyridyl described is a hexapyridyl of $\mathrm{mp} 350^{\circ} \mathrm{C}$. $)^{10}$ Since electroreaction schemes leading to polypyridyl would probably involve the formation of hydride, evidence was sought for the evolution of hydrogen during the reaction and for the presence of a hydride or of hydride anions in the catholyte just after the electrolysis. Hydride ions, if present in the latter catholyte, would react with water (added to the electrolysis cell from an attached burette ${ }^{1}$ ) with the evolution of an equivalent amount of hydrogen. The problem of determining small amounts of hydrogen with a minimum of operations involving transport of the hydrogen was solved by use of the electroanalytical fuel-cell method described in the Experimental section. 
Suitable experiments showed that, apart from extraneously introduced moisture, neither hydrogen is evolved nor hydride or hydride ions formed during electrolysis. Consequently, any hypothesis postulating formation of hydride cannot be supported.

Formation of a polymer. On the basis of the measured $n$ value of one per pyridine reduced (see subsequent discussion) and of the absence of bipyridyls, which are soluble substances with low melting points, it seemed possible that the pyridine ring might undergo fission during or after the cathodic process, forming an initial product A, which could then polymerize.

Electrolytic product $A$. A reaction path for the electrochemical reduction of pyridine solutions of $\mathrm{AlCl}_{3}$ can be developed, starting with the fact that $n$ for the polarographic reduction of the $\mathrm{Cl}_{3} \mathrm{Alpyr}_{3}$ complex (assumed to be mostly undissociated in the presence of the high concentration of lithium chloride used as background electrolyte) can be calculated from the Ilkovic equation by estimating the diffusion cocfficient of the complex from the Stokes-Einstein equation, using a valuc of 2 for the density of the complex (density of $\mathrm{AlCl}_{3}$ is 2.44 ; that of pyridine is 0.98 ); $n$ thus calculated is $2 \cdot 26$. A value of 2 is also indicated on comparing the diffusion-current constant of 3.5 found in reduction of pyridine solutions of $\mathrm{Cl}_{3} \mathrm{Alpyr}_{3}$ with those of 1.9 for $\mathrm{Tl}(\mathrm{I})(n=1)$ and of 3.0 for $\mathrm{Pb}(\mathrm{II})(n=2)$ in pyridine. ${ }^{1}$ Coulometry shows that one electron is transferred per pyridine molecule reduced. The slope of the polarographic wave of $c a 57 \mathrm{mV}$ indicates that the two electrons are singly transferred on to two pyridine molecules bound in the complex. Such behaviour leads to the reaction scheme
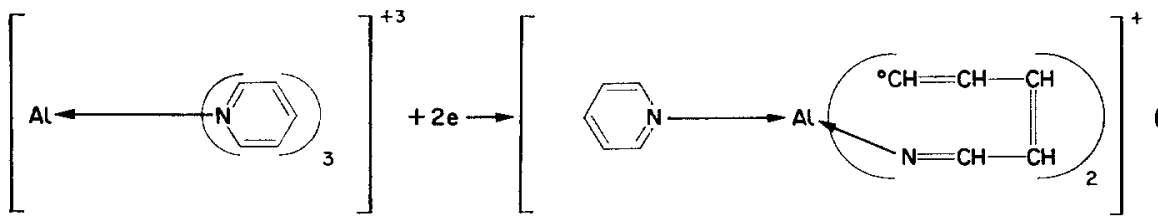

Product A

The slope of ca $57 \mathrm{mV}$, which is of the magnitude theoretically expected for a reversible one-electron transfer, would tend to indicate that the initial step in the electrode process involves a $1-\mathrm{e}$ reduction of the complexed and polarized pyridine molecule to a free radical anion, which is stabilized by complexing with the $\mathrm{Al}$ (III). The free radical anion may then preserve the ring structure, which would only open during subsequent hydrolytic processes in contact with water and air. A possible mechanism path for the latter process is subsequently described.

The $\mathrm{Al}(\mathrm{III})$ core in product $\mathrm{A}$ is surrounded by 8 electrons, which would fill its $3 s$ and $3 p$ levels. The resulting radical complex may be stable in the absence of air and water as the present studies indicate. However, the possible formation of the neutral complex cannot be completely ruled out.

\section{CHEMICAL REDUCTION OF PYRIDINE}

Since opening of the pyridine ring in the electrochemical reduction was suspected, it was decided to try a chemical reduction, which would simulate the electrochemical 
process. Reactions leading to ring opening have been described ${ }^{11}$ of the general type

$$
\mathrm{R}-\stackrel{+}{\mathrm{N}}+\mathrm{B}^{-} \rightarrow \mathrm{R}-\mathrm{N}=\mathrm{CH}-\mathrm{CH}=\mathrm{CH}-\mathrm{CH}=\mathrm{CH}-\mathrm{B} \text {, }
$$

where $\mathrm{R}$ is an electron acceptor and $\mathrm{B}^{-}$is a base. Because of the negative potential of the electrochemical reaction $(-1.6 \mathrm{~V})$, it was thought that a hydride ion would be a suitable base. As an electron acceptor, only Al(III) could be used, if analogous conditions were to be expected. Lithium aluminum hydride was consequently used; a mixture of lithium hydride and aluminum chloride might be equally effective.

The chemical reaction, described in the Experimental section, also yields four products: $A_{H}, B_{H}, C_{H}$ and $D_{H}$ (the subscript $H$ denotes that the product was obtained in the reaction of pyridine with lithium aluminum hydride). Spectroscopic evidence, analytical data and bromination experiments (subsequently discussed) indicate that products B, C and D obtained in the work-up of the electrochemical reaction are closely rclated to those obtained in analogous steps of the chemical reaction procedure. The evolution of hydrogen during addition of $\mathrm{LiAlH}_{4}$ to pyridine indicates that the two reactions differ mainly in the mode of the electron transport: in the electrochemical reduction electrons are supplied by the electrode; in the chemical reaction by the hydride. Both the electron and the hydride ion are considered here as bases. Thus, the two respective black primary products $A$ and $A_{H}$ may be expected to be closely related (if not identical) substances.

The possibility that product $A_{\mathrm{H}}$ might be a pseudoradical complex, such as lithium N-dihydropyridylaluminum hydride, ${ }^{12}$ was discarded since the latter compound would decompose into lithium aluminate and dihydropyridine on treatment with water or alkali (prior to separation of the final stable product). Dihydropyridines would remain in the organic phase and, being very unstable, would be easily oxidized by air back to pyridine ${ }^{11 b}$ rather than yielding the final stable polymeric product.

The reduction proceeds further when $\mathrm{LiAlH}_{4}$ reacts directly with pyridine than when it reacts in dilute ether solution. ${ }^{13}$

The reduced pyridine species, ie products $A$ and $A_{H}$, should be considered as anion radicals of high reactivity. Since they may contain chelate bonds to the $A 1$ ion (kernel) in place of a dissociated $\mathrm{C}-\mathrm{N}$ bond, reaction may be expected to occur and other final products obtained when-instead of water-oxygen, sulphur, $\mathrm{H}_{2} \mathrm{~S}$, halogens or other electrophilic or proton-donating reagents are added into a solution containing these radical complexes.

\section{DECOMPOSITION PRODUCTS B AND B}

As described in the Experimental section, decomposition of the black primary product of chemical or electrochemical reduction yields an oily product $B_{F}$ and $B$, respectively, whose infra-red spectra show characteristic features indicating that most of this material is a cyclic lactam, eg the $3280 \mathrm{~cm}^{-1}$ amide band observed in the spectra of products $\mathrm{C}$ and $\mathrm{C}_{\mathrm{H}}$ appears at $3180 \mathrm{~cm}^{-1}$, a frequency shift characteristic for cyclic lactams. ${ }^{14}$ Furthermore, the $\mathrm{CH}_{2}$ band at $1450 \mathrm{~cm}^{-1}$ is split; the one at $1470 \mathrm{~cm}^{-1}$ is the $\mathrm{CH}_{2}$ deformation (possibly cyclic methylene group) $;^{15}$ the other at $1420 \mathrm{~cm}^{-1}$ may be attributed to a methylene group in a six-membered ring adjacent to an unsaturated linkage, as this band is present in the spectrum of cyclohexene. ${ }^{15}$ Other absorption peaks appear at 2900,1645, 1595, 1070 and $810 \mathrm{~cm}^{-1}$. 


\section{POLYMERIZATION PRODUCTS C AND $\mathrm{C}_{\mathrm{H}}$}

Because of the polymerization of the product $\mathrm{B}$ obtained in both chemical and electrochemical reduction of $\mathrm{AlCl}_{3}$ solutions in pyridine, films on $\mathrm{NaCl}$ plates could be readily prepared. Infra-red absorption spectra of these films, dried at both $60^{\circ} \mathrm{C}$.

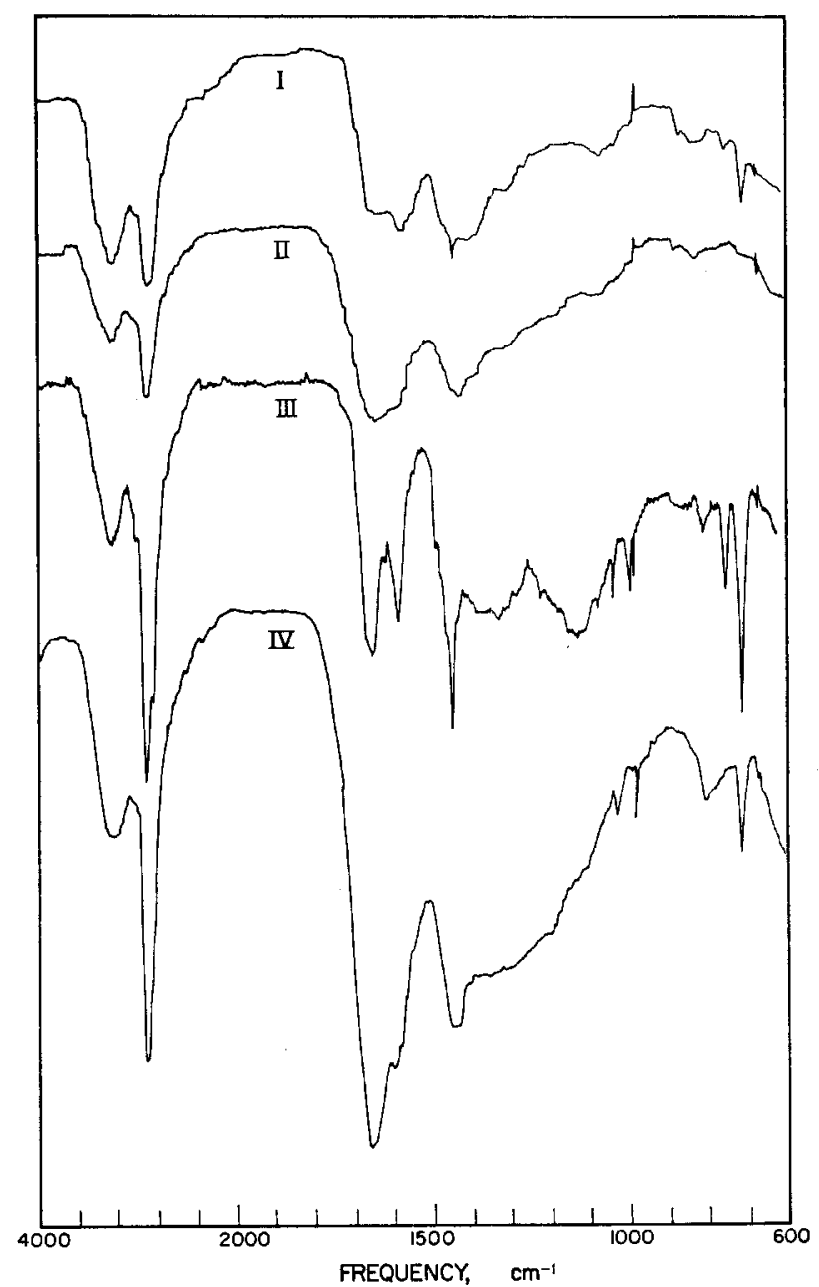

Fig. 1. Infra-red absorption spectra of the films made from treated products of the electrolysis (I, II) or $\mathrm{LiAlH}_{4}$ reduction (III, IV) of solutions of $\mathrm{AlCl}_{3}$ in pyridine

I: dried at $50-60^{\circ} \mathrm{C}$;

II: dried at $200^{\circ} \mathrm{C}$;

III: dried at $60^{\circ} \mathrm{C}$.;

IV: dried at $200^{\circ} \mathrm{C}$.

and about $200^{\circ} \mathrm{C}$., had absorption peaks (Table 1; Fig. 1) characteristic of a polyamide and were similar to the spectrum of Nylon. ${ }^{16}$ Spectra of the chemically reduced material were more distinct.

The infra-red spectra of both products $C$ and $C_{H}$ show a lack of bands characteristic of aromatic rings, especially of many of those characteristic of pyridine, 
TABle 1. INFRA-Red abSORPTION BANDS OF the ORGANIC PRODUCTS OF THE ELECTROCHEMICAL AND CHEMICAL REDUCTION OF PYRIDINE

\begin{tabular}{|c|c|c|c|c|c|}
\hline \multicolumn{2}{|c|}{ Electrochemical product } & \multicolumn{2}{|c|}{ Chemical product } & \multicolumn{2}{|c|}{$\begin{array}{l}\text { Comparative } \\
\text { absorptions }{ }^{15-19}\end{array}$} \\
\hline $\begin{array}{l}\text { Absorption } \\
\mathrm{cm}^{-1}\end{array}$ & Assignment & $\begin{array}{c}\text { Absorption } \\
\mathrm{cm}^{-1}\end{array}$ & Assignment & Material & $\begin{array}{c}\text { Absorption } \\
\mathrm{cm}^{-1}\end{array}$ \\
\hline & & $\begin{array}{c}4919 \\
4552 \\
4420-4390\end{array}$ & $\begin{array}{l}\text { poly-NH deformation } \\
\mathrm{C}=\mathrm{O} \\
?\end{array}$ & $\begin{array}{l}\text { Nylon } \\
\text { gelatine }\end{array}$ & $\begin{array}{l}4883 \\
4580\end{array}$ \\
\hline $\begin{array}{l}3240 \\
3000\end{array}$ & $\begin{array}{l}\mathrm{NH} \\
\text { trans } \mathrm{HC}=\mathrm{CH}\end{array}$ & $\begin{array}{l}3280 \\
3000\end{array}$ & $\begin{array}{l}\mathrm{NH} \\
\text { trans } \mathrm{HC}=\mathrm{CH}\end{array}$ & amides & $c a 3300$ \\
\hline 2900 & $\mathrm{CH}_{2}$ & 2900 & $\mathrm{CH}_{2}$ & polyethylene & ca 2900 \\
\hline 1645 & $\mathrm{NC}=\mathrm{O}$ (amide I) & 1655 & $\mathrm{NC}=\mathrm{O}($ amide $\mathrm{I})$ & amides & ca 1650 \\
\hline 1575 & $\mathrm{NH}$ (amide II) & 1585 & NH (amide II) & $\begin{array}{l}\text { secondary } \\
\text { amides }\end{array}$ & 1560 \\
\hline $\begin{array}{l}1450 \\
1400\end{array}$ & $\begin{array}{l}\mathrm{CH}_{2} \text { deformation } \\
\text { (skeletal vib? }\end{array}$ & $\begin{array}{c}1445 \\
1400-1200\end{array}$ & $\begin{array}{l}\mathrm{CH}_{2} \text { deformation } \\
\text { (skeletal vib ?) }\end{array}$ & & \\
\hline 1075 & $?$ & $\begin{array}{c}1030 \\
995\end{array}$ & $\stackrel{?}{\operatorname{trans} \mathrm{HC}}=\mathrm{CH}$ & & \\
\hline $810-840$ & (skeletal vib.?) & 805 & (skeletal vib. ?) & & \\
\hline 710 & $-\left(\mathrm{CH}_{2}\right)_{n}-$ & 710 & $-\left(\mathrm{CH}_{2}\right)_{n}-$ & polyethylene & 715 \\
\hline
\end{tabular}

$e g$ at 1920,1410 and $680 \mathrm{~cm}^{-1}$. Instead, bands characteristic of polyamides are present, eg $4919 \mathrm{~cm}^{-1}$ (comparable to Nylon 4883 due to polyamide NH deformation $^{17}$ ), $4552 \mathrm{~cm}^{-1}$ near the $\mathrm{C}=\mathrm{O}$ band observed in gelatine, ${ }^{16}$ the broad band around $3240 \mathrm{~cm}^{-1}$, and the well-known amide I and II bands.

The bands at 995 and $c a 3000 \mathrm{~cm}^{-1}$ are characteristic of the trans double bond, ${ }^{16,18}$ whose presence is in agreement with the bromination of the product (see Experimental). The $1595 \mathrm{~cm}^{-1}$ band may also be due to double bond vibration.

The three sharp bands at 2900,1450 and $710 \mathrm{~cm}^{-1}$, which are characteristic features of the polyethylene spectrum, ${ }^{14,16}$ indicate the presence of linear units in the structure of the product.

The close relationship of product $\mathrm{C}$ with product $\mathrm{C}_{\mathrm{H}}$ is also indicated by the similarity in properties and behaviour, eg in both manners of preparation black primary products $\mathrm{A}$ and $\mathrm{A}_{\mathrm{H}}$ appear during the reaction, which products react with water and oxygen to become pale-yellow precipitates having the following properties in common:

(a) General similarity of appearance, whether fresh or aged.

(b) Melting point of $392-5^{\circ} \mathrm{C}$ for both fresh and aged material. Samples begin to darken and to undergo apparent decomposition at $c a 250^{\circ}$.

(c) General solubility in acids, which decreases with time on exposure to air. However, even after such ageing, both products are soluble in hot mineral acids.

(b) General insolubility in water and common organic solvents. However, freshly precipitated products do show appreciable solubility in pyridine and methanol, which decreases rapidly on standing.

(e) Elementary analysis close to $\mathrm{C}_{5} \mathrm{H}_{7} \mathrm{~N}$ plus slightly different amounts of oxygen corresponding to one-third to une-half oxygen per formula shown.

(f) Increase in weight of the sample by a factor of 2.5 and 2.8 on bromination. A factor of 2.66 corresponds to bromination of one double bond in a molecule of formula weight $97\left(\mathrm{C}_{5} \mathrm{H}_{7} \mathrm{ON}\right)$. 


\section{MECHANISM OF PYRIDINE REDUCTION}

The evidence summarized shows that the pale-yellow product $\mathrm{C}$ and $\mathrm{C}_{\mathrm{H}}$, obtained after alkaline hydrolysis, is quite similar for both modes of preparation, and that it is a mixture or copolymer of unsaturated polyamines and polyamides. The latter assignment is in agreement with the chemical and physical properties, eg high melting point characteristic of linear polyamides and polyurethanes containing a trans double bond, ${ }^{16}$ solubility in acids and increased solubility in presence of salts $(\mathrm{NaCl})$ characteristic of polyamides, and the presence of one double bond per structural unit.

The electrochemical product $\mathrm{C}$ of composition $c a \mathrm{C}_{15} \mathrm{H}_{21} \mathrm{~N}_{3} \mathrm{O}$ may correspond to a mixture containing approximately two $\mathrm{C}_{5} \mathrm{H}_{7} \mathrm{~N}$ moieties such as $\mathrm{I}$ per one $\mathrm{C}_{5} \mathrm{H}_{7} \mathrm{NO}$ moiety such as II,<smiles>CNC1C=CC(C)C1</smiles>

(Io, $\mathrm{C}_{5} \mathrm{H}_{7} \mathrm{~N}$ )<smiles>CC1CC=CCN1</smiles><smiles>CCCC=CC(=O)NC</smiles><smiles>O=C1C=CCCN1</smiles>

(IIb, $\mathrm{C}_{5} \mathrm{H}_{7} \mathrm{NO}$ )

The chemical product $\mathrm{C}_{\mathrm{H}}$ has a composition near $\mathrm{C}_{10} \mathrm{H}_{14} \mathrm{~N}_{2} \mathrm{O}$. Allowing (as in all cases) for de-amination, this product may consist of approximately equal amounts of elementary units I and II. It is also possible that oxygen may have been added to the product in the initial steps of the reaction with water.

These considerations lead to the tentative reaction scheme

$$
\begin{gathered}
\text { Product } \mathrm{A}+3 \mathrm{H}_{2} \mathrm{O} \rightarrow \mathrm{Al}(\mathrm{OH})_{3}+\mathrm{C}_{5} \mathrm{H}_{5} \mathrm{NH}^{+}+\underset{\left(\mathrm{C} \mathrm{C}_{6} \mathrm{H}_{6} \mathrm{~N}\right)^{\circ}}{(\mathrm{III})} \\
2 \mathrm{OH}^{\circ}+2 \mathrm{I} \underset{+2 \mathrm{H}_{2} \mathrm{O}}{\longleftarrow} 2 \mathrm{III}+\mathrm{H}_{2} \mathrm{O} I+\text { II. }
\end{gathered}
$$

Based on the reversibility of the polarographic wave, as mentioned earlier, it is possible to formulate an alternative reaction path in which the primary electrolytic reaction proceeds without fission of the pyridine ring. The essential premise for such a mechanism would be that the black primary product of the electrolysis does not dimerize, since this would lead to the formation of bipyridyls, which are not observed. On alkaline treatment, the primary product ( $\mathrm{V}$, below) would be hydrolysed with the early addition of oxygen since hydrolysis without oxygen addition would probably lead to bipyridyl formation,

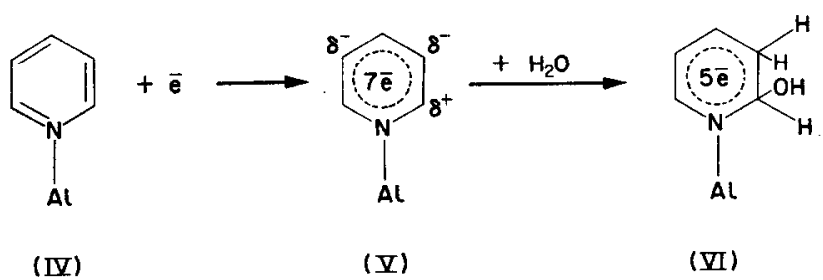


(Al indicates the aluminum(III) species co-ordinated to the nitrogen),<smiles>[Y10]OC1CC=CCC1CC1CC=CC(=O)N1</smiles>

(VII)

Formula VII corresponds to formulae I plus II. Opening of the lactam ring in VII (or its isomer) would result in a polyamine-polyamide polymer, which would correspond to product $\mathrm{C}$ and $\mathrm{C}_{\mathrm{H}} \cdot{ }^{11 \mathrm{~b}}$

The reversibility of the electron addition is not necessarily connected to the ring fission, since fission may well occur only after the electron is added and as a result of electronic rearrangement.

The reactions outlined above should be considered as skeletal schemes only. The actual course of the reactions is probably much more involved as indicated by the de-amination of the product (when compared with the parent pyridine), which de-amination occurs even at room temperature and, interestingly enough, to a similar degree for the products of both modes of preparation.

\section{HIGH-TEMPERATURE PRODUCTS D AND DH}

On exposure to air and heat, both pale-yellow products $\mathrm{C}$ and $\mathrm{C}_{\mathrm{H}}$ are slowly oxidized, as shown by elementary analysis. If this process is an auto-oxidation, perhaps similar to that described for hydrazone, ${ }^{19}$ then the oxidation may conceivably proceed through formation of a peroxide, which could split off water or oxygen and change into an unsaturated linear or branched secondary polyamide.

The position of the double bond in structural units I and II is indicated by the fact that the addition of oxygen in auto-oxidation usually occurs in a position alpha to the double bond. ${ }^{20}$ Since the presence of the $1650 \mathrm{~cm}^{-1}$ band in the infra-red spectra of our products indicates the presence of amide oxygen (in alpha position to the nitrogen atom), the double bond in the oxygenated species is written alpha to the amide group and, in the units which do not contain oxygen, beta to the amine group.

The amide II band is much weaker in the spectrum of the product $\mathrm{D}$ and $\mathrm{D}_{\mathrm{H}}$ dried at $c a 200^{\circ} \mathrm{C}$ than in that of the product $\mathrm{C}$ and $\mathrm{C}_{\mathrm{H}}$ dried at $60^{\circ} \mathrm{C}$; since the amide II band is absent in tertiary amides, this may indicate formation of a partially crosslinked tertiary amide.

Thus, the product $\mathrm{D}$ and $\mathrm{D}_{\mathrm{H}}$, from its infra-red spectra, seems to be an essentially linear polyamide, which may be partially cross-linked, as its melting point $\left(\mathrm{ca} 395^{\circ} \mathrm{C}\right.$ with decomposition) is quite high.

After the completion in early September, 1961 of the work described in this paper, we became acquainted with a study by Teodradze, Mairanovskii and Klyukina ${ }^{21}$ on the reduction of pyridine al a dropping mercury electrode. Along with the catalytic evolution of hydrogen, pyridine was apparently reduced with formation of a surface-active polymeric product. These authors do not give the reaction path, or the structure of their product; however, it is probable that their product may be 
quite similar to that observed by us. The reduction of pyridine may proceed similarly in strongly alkaline aqueous solution and dry pyridine; since the hydrogen-ion concentration in both media is very low, both media may be regarded as aprotic solvents.

\section{Chemicals}

\section{EXPERIMENTAL TECHNIQUE}

Aluminum chloride (Baker and Adamson reagent grade, anhydrous and sublimed) was used. The other reagents have been described, ${ }^{1}$ with the exception that metallic potassium was used as a test for dryness of the pyridine rather than as drying agent, in order to avoid possible contamination by reaction products; the pyridine was dried with Linde molecular sieves.

Macroscale electrolysis of pyridine- $\mathrm{AlCl}_{3}$ solutions

Electrolysis studies were made under a variety of conditions, using (a) $\mathrm{AlCl}_{3}$ concentrations from 0.01 to $0.15 \mathrm{M}$, (b) mercury pool, platinum sheets, copper wire or graphite rod $(0.25 \mathrm{in}$. diameter) as cathode, (c) platinum sheet, silver wire or graphite as anode, (d) a three-compartment cell, ${ }^{1}$ and (e) an automatic potentiostat. ${ }^{1}$ Since solutions of $\mathrm{AlCl}_{3}$ in pyridine are well conducting, no supporting electrolyte was used.

In order to obtain lower resistances, only two compartments of the cell and, for a few runs, only one compartment were used. The silver reference electrode was only used occasionally as the depolarization potential of the cathode reaction was found to be constant at about $-1.6 \mathrm{~V}$ vs NAgE, which is close to the polarographic $E_{1 / 2}$. In most cases a simple two-electrode electrolysis was made with the applied voltage being controlled with a rheostat; currents higher than $100 \mathrm{~mA}$ were obtained; the amount of electricity passed during an electrolysis was usually between 300 and $1200 \mathrm{C}$.

During electrolysis, the solution turned black after a few minutes and a black precipitate appeared; both of these, after addition of water or oxygen (air), became pale yellow. No metallic aluminum was detected in either the mercury cathode or the precipitate.

After interruption of the current, the catholyte and black precipitate which had formed (product A) were quickly pourcd into a separatory funnel containing concentrated aqueous $\mathrm{NaOH}$ solution. The mixture was shaken and, after a while, separated into two layers. The lower aqueous layer, which contained aluminate (usually as a white precipitate), $\mathrm{NaOH}$ and, when the reaction mixture was from the chemical reaction, $\mathrm{LiOH}$, was rejected. The upper layer, which contained the organic product, partly dissolved in pyridine and partly present as a flocculent yellow precipitate, was centrifuged or decanted to remove the precipitate; samples for infra-red examination were prepared by one of the following procedures:

(a) The pyridine layer was rapidly evaporated on a large watch-glass in a stream of air (under a hood) with gentle heating $\left(c a 60^{\circ} \mathrm{C}\right)$. After an hour or so a thin film formed on the surface of the residual solution. A rock-salt plate was covered with the film by making an opening in the film with a spatula and slipping the plate benteath the film. The plate with the film was placed in a desiccator containing $95 \% \mathrm{H}_{2} \mathrm{SO}_{4}$ and left for 2-3 days to allow absorption of pyridine and water from the film. Infra-red spectra were then recorded. Subsequently, the plate was dried in an oven 
(with access of air) at about $200^{\circ} \mathrm{C}$ for $2-3 \mathrm{~h}$; spectra were then recorded on the dried film. This procedure gave compact, smooth films of the products, which allowed observation of $\mathrm{CH}$ bands (usually veiled by the Nujol absorption) and, moreover, largely eliminated the possibility of contamination with adsorbed and/or absorbed moisture. Spectra reproduced in Fig. 1 were thus obtained.

(b) To the pyridine layer, 4-6 volumes of anhydrous ethyl ether were added, resulting in a white-yellowish precipitate, which was rapidly filtered, washed with ether and placed on rock-salt plates. On exposure to air, the precipitated material apparently "melted", forming a yellow oil (product B) which later solidified on the plate. After the oil formed, the rock-salt plates were placed in the desiccator containing $96 \% \mathrm{H}_{2} \mathrm{SO}_{4}$ and, after $2-3$ days, spectra were recorded as in procedure (a).

(c) An excess of water was added to the pyridine layer. The resulting pale-yellow precipitate was washed with water. Infra-red spectra of this material were less distinct than those obtained by procedure (a) or (b), but were in agreement with them.

Ignition of the washed and dried precipitate (product $C$ ) gave $0.5-2 \%$ ash, which had an alkaline reaction with water. Emission spectrographic analysis of an ash, which amounted to $0.79 \%$, revealed $\mathrm{Na}, \mathrm{Mg}$ and $\mathrm{Ca}$ around $0.1 \%, 0.01-0.1 \%$ $\mathrm{Al}, \mathrm{Fe}$ and $\mathrm{Si}$, and a trace of $\mathrm{B}$.

The pale-yellow product $\mathrm{C}$, washed and dried at $c a 60^{\circ} \mathrm{C}$, has an average composition of $68.9 \% \mathrm{C}, 8.2 \% \mathrm{H}, 13.9 \% \mathrm{~N}$, and $5.4 \% \mathrm{O}$ (average total: $96.4 \%$ ), corresponding to an empirical formula of $c a \mathrm{C}_{15} \mathrm{H}_{21} \mathrm{~N}_{3} \mathrm{O}$. It may be noted that (a) an atomic ratio of $\mathrm{C}: \mathrm{N}$ greater than 5 would indicate partial de-amination as compared with the substrate (pyridine), which might lead to partial cross-linking of the polymeric product, and (b) a low oxygen content would indicate that the product is a mixture or copolymer. Drying in air causes darkening and apparently results in de-amination and further addition of oxygen as evidenced by the elemental composition of the dark-brown or black product $\mathrm{D}$ obtained after drying the pale-yellow precipitate at $c a 180^{\circ} \mathrm{C}$.

Titration of product $\mathrm{C}$ in glacial acetic acid with $\mathrm{HClO}_{4}$ gave an equivalent weight of $c a 130$. The perchlorate salt (yellow), which precipitated during titration, was shown by $\mathrm{Cl}$ analysis to be a $1: 1$ salt with $\mathrm{ClO}_{4}^{-}$; it is less soluble in acetic acid than pyridinum perchlorate.

The $n$-values, calculated from the lotal amount of electricity passed and the weight of the insoluble washed and dried product expressed in moles of pyridine (which was the starting material), were $1 \cdot 0 \pm 0 \cdot 2$. Other properties were similar to those observed for the $\mathrm{LiAlH}_{4}-$ pyridine reaction product and are described together with those of the latter.

The catholyte resulting from electrolyses of $0.01-0.15 \mathrm{M} \mathrm{AlCl}$ solutions at platinum, carbon and mercury electrodes, was hydrolysed in $20 \% \mathrm{HCl}$, treated with various acids, bases and common organic qualitative reagents, especially those used to detect amines and amides, but no characteristic derivatives were obtained. The only interesting derivative was a refractory material which did not melt or decompose below the softening point of the glass mp capillary.

\section{Reaction of $\mathrm{LiAlH}_{4}$ with pyridine}

Addition of solid $\mathrm{LiAlH}_{4}$ to dry pyridine results in a self-sustained exothermic reaction with dissolution and evolution of hydrogen. When less than about $8 \mathrm{~g}$ 
$\mathrm{LiAlH}_{4}$ is added per $100 \mathrm{ml}$ of pyridine, a black opaque solution results. With larger amounts, the solution solidifies on cooling to a black mass (product $A_{H}$ ), which can be kept indefinitely when protected from moisture and air. After the reaction mixture cooled, it was processed in the same way as the catholyte obtained in electrolysis.

During work-up, the products $B_{H}, C_{H}$ and $D_{H}$ successively appeared with properties very similar to those of products $\mathrm{B}, \mathrm{C}$ and $\mathrm{D}$.

Yellow product $C_{H}$ has an ash content of $0 \cdot 0-0.5$ per cent, a melting point of about $395^{\circ} \mathrm{C}$ (with decomposition), and chemical properties and infra-red absorption spectra (Table 1) after polymerization very similar to those of the product obtained on electrolysis. However, product $\mathrm{C}_{\mathrm{H}}$ contains more oxygen. After drying at $\mathrm{ca}$ $180^{\circ} \mathrm{C}$ a dark-brown to black material is obtained of relatively decreased nitrogen and increased oxygen content.

\section{Bromination procedure}

Organic products isolated from electrolysis and the chemical reaction were brominated essentially as suggested by Rossmann ${ }^{22}$ : A weighed amount (30-80 mg) of product was thinly smeared on a glass plate, which was exposed to bromine vapor in an opaque desiccator for $12 \mathrm{~h}$. The plate was then exposed to air for a few min to allow most of the excess bromine to volatilize, transferred to a desiccator containing $\mathrm{NaOH}$ flakes for 2 or 3 days, and then weighed to obtain the increase due to bromine absorption. Since the bromination products decomposed appreciably above $60-80^{\circ} \mathrm{C}$, their melting points could not be determined.

\section{Apparatus}

The polarographic and electrolysis apparatus used have been described. ${ }^{1}$ Infrared spectra were measured on a Perkin-Elmer Model 21 spectrometer, using a rock salt prism for $4000-600 \mathrm{~cm}^{-1}$ and a $\mathrm{CaF}_{2}$ prism for $5000-4000 \mathrm{~cm}^{-1}$. Melting points were determined in sealed capillaries in an aluminum block, using a $280-600^{\circ} \mathrm{C}$ thermometer.

Gas cell for hydrogen determination. The cell, which is essentially a modification of one devised by Dassler, ${ }^{23}$ consisted of an inverted $180-\mathrm{ml}$ tall Pyrex beaker, filled with $\mathrm{KOH}$ solution ( 1.20 density), standing in a crystallizing dish filled with the same solution and containing a 30-mesh nickel gauze electrolytically covered with palladium. A similar gauze was wound on the outside of the beaker and immersed in the $\mathrm{KOH}$ solution with free access of air; the solution was stirred to bring oxygen into contact with the gauze.

When the cell was tested by the Dassler procedure, the presence of an appreciable residual current introduced an error in the measurement. However, it was observed that, when $\mathrm{H}_{2}$ was in the cell, a potential was immediately established between the inner electrode (immersed in $\mathbf{H}_{2}$ ) and the outer electrode (immersed in a solution saturated with air). That this potential difference originated from reduction of $\mathrm{O}_{2}$ at one electrode and oxidation of $\mathrm{H}_{2}$ at the other, resulting in a classical type of fuel cell, proved to be the case, since, on disconnecting the power supply and shunting the two electrodes through a milliameter, currents up to $100 \mathrm{~mA}$ were observed and the $\mathrm{H}_{2}$ in the cell was consumed. This method was then used for the determination of $\mathrm{H}_{2}$, ie after a gaseous sample has been added to the beaker, the electrodes are simply 
shunted through a silver coulometer, which is used to measure the amount of electricity transferred in the quantitative oxidation of $\mathbf{H}_{2}$.

In view of the current interest in fuel cells, it is worth emphasizing the analytical potential of such systems as evidenced by the simple cell described (the potential of this cell was about $0.4 \mathrm{~V}$ at currents of $1 \mathrm{~mA}$ ).

The cell described may obviously also be used to determine $\mathrm{O}_{2}$ by covering the outer electrode of the cell with another, larger beaker to form a two-compartment cell. If gaseous $\mathrm{H}_{2}$ is then introduced into one compartment, the $\mathrm{O}_{2}$ content of a gaseous sample in the other compartment (beaker) may be conveniently determined by connecting the two electrodes through a coulometer.

Acknowledgements--The authors wish to thank the U.S. Atomic Energy Commission, which helped support the work described, and Dr. David L. Smith of the Upjohn Co. for help with the analysis of the products obtained.

\section{REFERENCES}

1. A. Cisak and P. J. Elving, J. Electrochem. Soc. 110, 160 (1963).

2. B. EMMERT, Rer. 46, $1716(1913)$.

3. C. Marie and G. Lejeune, J. Chim. phys. 22, 59 (1925).

4. M. S. Spritzer, J. M. Costa and P. J. Elving, Analyt. Chem., 37, 211 (1965).

5. E. Garber, L. Pease and W. F. Luder, Analyt. Chem. 25, 581 (1953).

6. E. T. Hirchcock and P. J. Elving, Analyt. Chim. Acta 27, 501 (1962).

7. W. F. Luder and S. Zuffanti, Electronic Theory of Acids and Bases. Wiley, New York (1946).

8. H. Luther, D. Mootz and F. RADwiTZ, J. prakt. Chem. [4], 5, 242 (1958).

9. M. H. Dilke, D. D. Eley and M. G. Sheppard, Trans. Faraday Soc. 46, 261 (1950).

10. F. H. Burstall, J. Chem. Soc. 1938, 1662.

11. (a) T. ZnNCKe, Ann. 330, 361 (1904); (b) R. A. BARnes, in Pyridine and Its Derivatives, ed. E. Klingsberg, Part 1, p. 58. Interscience, New York (1960).

12. P. T. Lansbury and J. O. Peterson, J. Amer. Chem. Soc. 83, 3537 (1961); 84, 1756 (1962).

13. F. BoHLMan, Chem. Ber. 85, 390 (1952).

14. L. J. Bellamy, The Infra-Red Spectra of Complex Molecules, 2 nd ed., chapters 2,3 and 12. Wiley, New York (1958); H. M. Randall, R. G. Fowler, N. Fuson and J. R. Dangl, Infra-Red Determination of Organic Structures. Van Nostrand, New York (1949).

15. R. N. Jones and A. R. H. Cole, J. Amer. Chem. Soc. 74, 5648 (1952).

16. W. BRÜGEL, Einführung in die Ultrarotspectroskopie, Part IV, Chapter 3. Steinkopf, Darmstadt (1954).

17. L. Glatt and J. W. Ellis, J. Chem. Phys. 15, 884 (1947); 16, 551 (1948).

18. L. Crombie, Quart. Rev. 6, 101 (1952).

19. R. Criegee and L. Lohaus, Ber. 84, 219 (1951).

20. C. Wallng, Free Rudicals in Solution, Chapter 9. Wiley, New York, (1957).

21. G. A. Teodradze, S. G. Matranovskil and L. D. Klyukina, Izvest. Akad. Nauk SSSR, Otdel. Khim. Nauk 1352 (1961),

22. E. Rossmann, Ber. 65, 1847 (1932).

23. A. Dassler, Angew. Chem. 50, 725 (1937). 